\title{
A LOVER'S GUIDE TO BREAKFAST PLACES
}

\author{
Gabriela Lee \\ University of the Philippines \\ gabriela.dans.lee@gmail.com
}

\begin{abstract}
About the Author
Gabriela Lee has been published for her poetry and fiction in the Philippines, Singapore, the United States, and Australia. Her first book of prose is titled Instructions on How to Disappear: Stories (Visprint Inc., 2016). Her previous works include Disturbing the Universe: Poems (NCCA Ubod New Writers Prize, 2006) and La-on and the Seven Headed Dragon (Adarna House, 2002). She has received a Master of Arts in Literary Studies from the National University of Singapore (NUS), and currently teaches literature and creative writing at the University of the Philippines, Diliman. You can find her online at www.sundialgirl.com.
\end{abstract}


Place: Bernie’s Bakery

Address: \#24 Goldenrod Street, Petersville Village Phase 2, Fairview, Quezon City

Opening Hours: 4:00 AM to 4:00 PM

Must-Try: Kapeng barako with muscovado sugar, fresh pan de sal with kesong puti

Best During: Hot mornings, when you wake up and your body is sticky with sweat and the single electric fan in your room can barely dispel the heat. You push away your sheets and decide to get breakfast. You put on your high school batch t-shirt, the one that clings to your curves because the cotton is too old, and you don't even bother to wear a bra. Modesty is only a concern when there's sunlight; right now, nobody will see you wearing an old shirt and older shorts.

You bring your wallet with you, but you leave your phone behind. You hope that she does not message you today.

Outside, the lamplight flickers, throwing shadows in sharp relief across the asphalt. Cars are parked on both sides of the street. There is a rooster tied to a piece of rebar sticking out from your neighbor's newly cemented wall, eyeing you suspiciously. There are stray dogs roaming the streets, sniffing the piles of garbage bags that have been placed on the sidewalk, waiting to be collected. You avoid them. You've heard of the stories: how dogs can smell fear, that their bite can sever arm from socket, skin from bone. You do not want to be broken.

Bernie's is just across the street from your apartment. The glass door is locked, but there is a light coming from inside the bakery. You rap on the glass and wait for the girl at the counter to unlock it. Inside, you are swallowed by the warmth. There are four small square tables inside the bakery, each with a set of chairs. Shelves line the longest wall, filled with baking ingredients like flour and sugar and baking powder. There's jam jars and packaged coffee grounds and all sorts of produce that Bernie purchases from his suppliers on a regular basis. He doesn't encourage people to stay for long, but he wants you to buy stuff. The display counter is already being filled with trays of breakfast pastries for the morning crowd: pan de coco, Spanish bread, Tasty loaves, pan de regla, puto and colorful kutsinta. You glance at the old wall clock hanging on the faded orange walls. It's not even 5 o'clock in the morning, and all you want is a bag of pan de sal and maybe some coffee, black like the empty spaces in your room.

You don't have your phone with you. You wonder if she will still show up. 
You step up to the counter and place your order-a cup of coffee, half-a-dozen pan de sal in a brown paper bag, a pat of kesong puti to fold into the warm, pillowy softness of the bread. You love biting into the pan de sal: how the brown crusty exterior crumbles in your mouth to give way to the white, airy texture of the bread. You know that this is what clouds must taste like. You hand your payment to the sleepy girl at the counter and wait for her to count your change when you hear the door open behind you. You don't turn your head.

You regret that decision instantly because when you turn around, Macky is standing in front of you; she's recognized you even before you looked at her. She's wearing a ratty t-shirt and leggings, and purple-painted toes peek out from her rubber flip-flops. She gives you a tentative smile: "Hey, Becca. Nice to see you."

The pan de sal is no longer tempting to touch. The small bakery is suddenly smaller, the walls closing in as you struggle to breathe. You can hear your heart slamming against your chest. Sweat beads across your forehead, drips down the side of your face, collects at the neckline of your shirt. This is the closest you've seen her in the past month. She's so close that you can smell the familiar scent of her perfume.

You try not to show her that you're spooked. "Stop following me," you whisper as you circle around her presence, careful not to touch her, and head to the door.

You hope that you don't see her again.

Place: The Breakfast Post

Address: Unit C,\#172 Maple Street, Petersville Village Phase 2, Fairview, Quezon City

Opening Hours: 7 AM to 9 PM

Must-Try: Homemade apple cider, ube pancakes with toasted coconut flakes, cereal milk ice cream

Best During: A summer courtship, when the days are hot and the nights even hotter, and you feel like you might explode from all the desire bubbling inside your body. Each touch from Macky is like wildfire: consuming vast swaths of your mind, filling it with the scent of her perfume. Each sound from her lips drip like water in a desert, and you drink every last drop. She clings to you, her hair damp with 
sweat, her body arching around yours like a perfect parabola. You let her ride out her orgasm. You never reach your own pleasure.

She is always hungry after sex, especially since you only see each other sporadically. You enjoy taking her to a neighborhood breakfast place, one that serves an all-day set menu. It is small and quaint, each table seating four people, a lamp hanging above each shiny surface. The walls made of planks of unpainted wood. There are high shelves full of small porcelain knickknacks: a salt-and-pepper nested chicken, a small replica of a New England house covered in ceramic snow, a set of brightly-colored matryoshka dolls. Macky adores their pancakes and always orders too many food. You end up finishing what she can't eat anymore, because your mother taught you not to waste food.

You wonder how your mother would feel if you told her you have a girlfriend. You wonder if Macky will ever tell her family about you. But those thoughts spiral helplessly around your head, until you find your thoughts unmoored from the harbor of the present moment, where you and Macky are together. You sling your arm around Macky's waist, your hand settling into the curve of her waist as though it belonged there.

"It's warm, Becs," she says, shifting away from your grasp.

"I'm sorry," you say, leaning away and slipping your hand away from her body. You feel lost, somehow; unanchored to the shoreline of her skin.

"You don't have to be clingy all the time."

"I'm not being clingy."

"Yes you are," Macky laughs. "Don't worry, I'm not going anywhere."

That night, you lie beside her, your back against the wall as you watch her sleep. You wonder how you were able to get her to agree to stay the night. She will be gone before you wake up-her day starts at seven in the morning, while yours begins right after one in the afternoon. Today is a rare day, when your schedules are in sync. Her face is relaxed, her lips parted slightly to form an O. Her bangs brush her forehead. She sleeps on her back, her arms around her midsection, the sheets tangled around her legs. You wonder what she is dreaming about. She mumbles something, her brow furrowing as though she is thinking about an answer to a difficult question. You reach out and sweep her bangs away from her face, try to see it clearer in the faint moonlight. She flinches slightly, as though she's been touched by a ghost. 
Place: Roderic's Sinangag and Stuff

Address: Unit A-D, Lower Ground Floor, HCG Tower 3, Ortigas Business District, Pasig City

Opening Hours: 24 hours

Must-try: Tapsilog, pork barbecue, arroz caldo

Best During: A planned workday meet-up, at the heart of the business district, when you haven't seen her in days. She's busy at work with a new project, she says, and you say that you understand. You were also just given a new schedule that you had to adjust to, which meant that while she was asleep, you were answering customer service phone calls from Ireland and Scotland. The accent is thick on your tongue, and you hate that you can barely twist your lips to mimic the sound of their English. You're frustrated and tired, stabbing the piece of pork on your plate like it had disappointed you personally.

You wonder when the two of you will finally stop working long enough to meet in the middle again.

Macky messages you just as your lunch break ends and you have to hustle back to your building before your supervisor declares that you're late and docks your pay. You check the screen as you pile the dirty plates from your table and deposit it to the counter, where the red-uniformed boy gives you a gap-toothed smile. Macky says she's got a deadline looming and she's already doing OT for the past three days, and if it's okay she can just call you later, during your 15-minute break. She tells you that she loves you. You shake your head ruefully at the multitude of smiley faces that follow her apology.

You wish for the days when you had breakfast together again, when you could hide the two of you away from work and deadlines and pressure from your family and hers-when are you getting married, Rebecca, you hear your mother whine in your mind, I'm not getting any younger and your womb's starting to shrivel up-and the world, the world hates people like you. This is why you like the places in your neighborhood: nobody stares when you hold hands, or when she kisses your cheek in the middle of a meal.

Just thinking about her makes your heart ache. You understand why people miss each other: it is an act of absence, of removing a vital part of living from the picture, 
excising what is needed to survive and forcing you to pay attention to that lack. You shake your head; you're not used to being philosophical in the middle of a workday.

During your shift, you pull out your phone from your desk drawer again and stare at the message while someone on the other side of the world yells in your ear about something that you didn't have control over, that you couldn't even know about. You stare at the emojis on the screen, Macky's last words glowing against the glass, and you wonder when you'll have time to see her tomorrow.

\section{(Of course you will.)}

You get out at 3:30 in the morning: you and your floor mates stream out of the automatic double doors of your office building, your eyes bleary and tired. The company shuttles are waiting in the parking lot. Most of the people you work with gather around lampposts, shadowy areas, the light of a flickering flame sparking as cigarettes are lit. Smoke hangs over small groups. Everyone is exhausted.

But you decide to walk the two blocks to Macky's favorite tapsilog place again. It's open 24 hours, like most breakfast places in the area, and there's already a sizeable crowd inside. You think about buying her breakfast; you can wait a couple of hours before she wakes up. You stand in line at the counter, peruse your choices. You check your phone. There's still no message from her. (She's probably asleep.) But that doesn't matter. You're always willing to wait.

Place: Marymount Station

Address: \#2 Circumference Road, Baguio City

Opening Hours: 8 AM to 10 PM

Must-Try: Benguet coffee, strawberry shortcake, bagnet fried rice

Best During: An out-of-town trip that you've been planning for more than a month. One of the things that nobody's ever said about being in a relationship is the sheer amount of work you need to do in order to make sure that your schedules match. You envy the couples who work normal hours, or those who work in the same office-their difficulties aren't as bad as yours. After all, when your schedule shifts every few weeks, and Macky's schedule fluctuates because of the campaigns she's handling as art director in an ad agency, any kind of weekend where the two of you have the chance to spend time with each other is a godsend. 
So you take the midnight bus to Baguio, holding hands underneath the fluffy blanket that you brought along, Macky's face obscured by a wool beanie that she had pulled over her eyes. The bus ride was uneventful, and you arrived at the bus station just as the sun was coming up. Macky yawned and stretched and made purring noises, which you refused to admit that you found them adorable, and began whining about breakfast.

You hail a cab and head towards the bed and breakfast that you reserved online. Once you've checked in, the owner recommends a restaurant near Session Road that serves the best bagnet fried rice in the city. Macky's eyes widen in excitement, and for the first time, she takes the lead and drags you out the door.

The place has high ceilings and wide windows, with drapes falling all the way to the floor in a dramatic line. The floor is hardwood, shiny and dark with age, and the tables are elegantly set, with fresh flowers at the center. The two of you are ushered to a table that overlooks the restaurant garden, where there is a profusion of blooms decorating the greenery. Beyond the garden, the city spreads out beneath your gaze. A ring of clouds touch the mountaintops.

Macky breathes out, relaxes. "This is beautiful."

You reach for her hand across the table. "Happy anniversary," you say.

She gives you the widest smile you've ever seen on her face. You want to kiss her.

The waiter gives you a menu, and you peruse their breakfast offerings. Both of you get coffee, an assortment of bread. She orders the fried rice and scrambled eggs, and you know she'll never finish her food. But it doesn't matter; you'd eat out of her hand if she wanted you to.

Just as the waiter steps away, her phone rings. She meets your gaze, silently asking for permission.

"We're on vacation," you insist.

"It's work," she replies.

She answers it, turning her face away as she shifts from lover to art director. You can hear the clipped diction of her voice, the displeasure threading beneath her even tone. She asks question after question, pinching the bridge of her nose with her thumb and forefinger as she tries to figure out how to help her colleagues without sacrificing your weekend together. 
Finally, she ends the call, and you already know that you'll be exploring the city on your own today.

Macky is already pulling out her Macbook Air out of her bag and moving the table settings so that she has space. You watch her mutely, trying to stop the tears from falling. "I thought we had more time," you say.

She does not meet your eyes. "I'm sorry, Becca. I thought that we had more time, too."

Place: DD3 Delivery

Address: Unit 2-16, Jubilee Condominiums, Jose Vargas Llosa Street, Capitol Crest, Makati City

Opening Hours: 24 hours

Must-try: Tinapa breakfast rolls, bangus belly

Best During: A long night sitting outside someone's apartment hallway, waiting for them to come home. The night guard is asleep when you enter the lobby and head towards the elevators, to the $11^{\text {th }}$ floor of Macky's condo block.

You don't have a key to her place; she has a key to yours. But you've already gone to your place before heading to hers, changing out of your button-down and slacks to a comfy pair of jeans and one of the shirts she gave you. You're not fond of plaid, but she likes them, so you wear it for her. The tapsilog you bought for her is in a white plastic bag. The grease has already soaked through the thin cardboard packaging.

You ring her doorbell twice, hearing the buzz echo dimly behind the door. There are no other sounds coming from her apartment; you press your ear against the cool synthetic surface of her door and you hear nothing. You make yourself comfortable outside her apartment, sitting down on the hard tiles and leaning your head against the concrete wall opposite the entrance. Your watch says it's almost 6 o'clock. The world around you is waking up.

From your position on the floor, you watch as Macky's neighbors begin leaving their apartments and heading towards the elevators in the center of the building. You watch girls and boys in school uniforms run or walk or slump towards the 
elevators, their yayas trailing after them with their bags. You watch as executives in expensive three-piece suits stride down the hall, their expensive cellphones pressed against their expensive ears, money rising and falling with every breath. You stare at your own battered phone with a 10\% battery life, and you wonder if those are the kinds of people Macky works with.

Sometimes, you wonder why she's still with you.

You doze off. You're vaguely aware of people walking down the hallway-water delivery, laundry service, cleaning ladies in uniforms. You hope that nobody calls the guard. You see a familiar tan-and-green uniform, and you're pleased to see that the breakfast place that's located at the basement of the building is still handing delivery orders. The number is saved on your phone because you love their food, even though Macky hates having dried bangus for breakfast because all the bones get stuck in her throat. Whenever you stay at her apartment, you always call them for food; the delivery guy, Kuya Bong, already knew you by face.

It's Kuya Bong who spots you in front of Macky's apartment. He drags you to your feet and gives you a tight hug. "Aren't you supposed to be at the wake?" he asks you.

Place: Blossom and Brews

Address: 02-32 Rail Strip Mall, Capitol Crest, Makati City

Opening Hours: 9 AM to 7 PM

Must-try: Brazo de mercedes, Spanish hot chocolate, rosehip tea

Best During: A period of grieving. You've gone through a packet of tissues but you can't seem to stem the tears. The server quietly refills your teacup with freshly boiled water. You watch the leafy debris swirl in your cup, tinting the water with pink. Macky hates-hated_pink; she said it washed out her complexion.

You do not know how to start thinking about her in the past tense.

You do not know how to start living without her in the present.

Her death only merited a short update on social media feeds, a sentence or Twitter: "Art director dead after three days of OT." The article linked to the status 
update spoke about Maricris Santacruz, 34 years old, who worked with the agency Salonga \& Rodriguez \& Saqueton for five years, who hadn't gone home or slept in three days, who was handling the pitch for a multinational diner chain when she had a heart attack on her desk. There were soundbytes from her colleagues, from her direct supervisor; a quick quote from a psychologist who spoke of being overworked; a medical explanation for cardiac arrest. (You wonder if your heart can break from this information as well.) It spoke about her wake, where to pay respects, the names of her family members. You are not surprised you missed the news - how can her family and friends contact you if you don't exist in their world?

You scroll through the newsfeed, look through the comments. A lot of people are complaining about work stress, about how they are treated poorly by their companies. You can see the fractures in their words, the grinding syllables between their teeth as they try to figure out how they could prevent this from happening to them. Macky wasn't meant to be an example; she wasn't meant to die. She was meant to meet you after work. She was meant to be with you for a lifetime. You don't want to visit her Facebook - the two of you had long decided not to tag each other in photographs. Your status still says "Single."

Today would be the first time in two years that this will be true.

Your phone is filled with pictures of her: moments frozen in time. You see her smile float on the screen, the sun behind her, her hands clasping a mug of coffee. You cannot remember where this was. Is this how it will be? A slow forgetting of places and names and moments stolen from the world? You brush away the tears stinging your eyes.

Your phone buzzes with a message. It's from Macky's number.

\section{I'm on my way.}

You look up. You are seated at the far end of the cafe, beside the window that overlooks the busy street. Traffic runs both ways: cars and trucks and motorcycles speeding across street like waves churning across an angry sea. You watch the cars slow down, the traffic lights turning red, the MMDA traffic enforcer escorting pedestrians to the other side. You see a familiar girl waving her hand, trying to catch your eye. 